\title{
Synthesis of Fluorene-Based Oligomeric Organoboron Reagents via Kumada, Heck and Stille Cross-Coupling Reactions
}

Xiaojie Zhang, Hongkun Tian, Qin Liu, Lixiang Wang, Yanhou Geng ${ }^{*}$ and Fosong Wang

\section{Supporting Information}

\section{Contents}

1. Scheme S1. Synthesis route of intermediates and target compounds.

2. General methods and synthesis.

3. Key references for synthesis.

4. ${ }^{1} \mathrm{H}$ NMR spectra of intermediates and target compounds.

$\mathbf{1 a}$ - page $S 11 ; \mathbf{1 b}$ - page $S 12 ; 2$ - page $S 13 ; 3$ - page $S 14 ; 4$ - page $S 15 ; 5$ page S16; 7 - page S17; 2,7-bis (2,2'-bithien-5-yl)-9,9-dioctylfluorene - page S18; 8 - page S19; 9 - page S20; 11 - page S21.

5. GC-MS of compound $\mathbf{1 a}$ and $\mathbf{1 b}$.

1a - page S22 and 23; $\mathbf{1 b}$ - page S24 and 25.

6. UV-vis absorption spectra of compounds 7, 9, 11 .

*E-mail: yhgeng@ciac.jl.cn 
Scheme S1. Synthesis route of intermediates and target compounds.

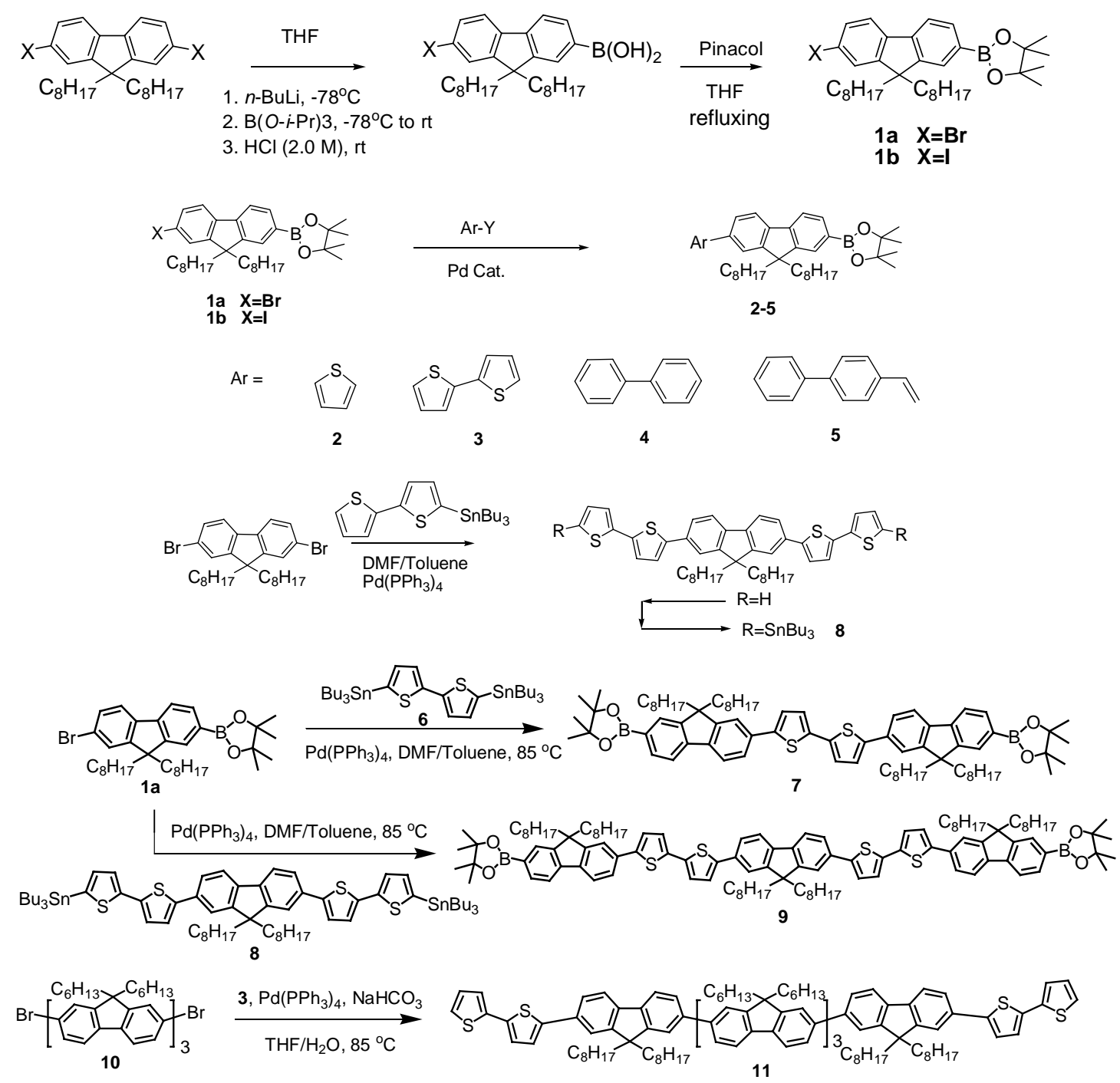

General. Nuclear magnetic resonance spectra were taken on a $300 \mathrm{MHz}$ spectrometer.

Chemical shifts are reported relative to internal tetramethylsilane. Molecular mass was measured with MALDI-TOF mass spectrometer or Gas Chromatography-Mass spectrometer. The purity of the compounds was characterized with High Performance Liquid Chromatography (HPLC).

Materials. All chemical reagents and solvents were used as received from 
commercial sources without further purification except ethyl ether, tetrahydrofuran (THF) and toluene that had been distilled over sodium/benzophenone. 2,7-Dibromo-9,9-dioctylfluorene and 2,7-diodo-9,9-dioctylfluorene ${ }^{[1]}$; thienyl magnesium bromide ${ }^{[2]} ;$ 2-Tributylstannylthiophene, 5-tributylstannyl-2,2'-bithiophene, 5,5'-bis(tributylstannyl)-2,2'-bithiophene and 4-tributylstannylbiphenyl ${ }^{[3]}$; 4-phenylbenzaldehyde ${ }^{[4]}$, 4-phenylstyrene ${ }^{[5]}$ and 2,7"'-dibromo-[9,9,9',9',9",9"hexahexyl] $-7,2^{\prime} ; 7^{\prime}, 2^{\prime \prime}$-terfluorene $(\mathbf{1 0})^{[6]}$ were synthesized according to the reported methods. ${ }^{1} \mathrm{H}$ NMR spectra of these compounds are identical to those reported in the references.

\section{7'-Bromo-9',9'-dioctyl-fluoren-2'-yl-4,4,5,5,-tetramethyl-[1,3,2] dioxaborolane}

\section{(1a)}

Into a solution of 2,7-dibromo-9,9-dioctylfluorene (7.27 g, $13.3 \mathrm{mmol})$ in anhydrous THF $(130 \mathrm{ml})$ was added $n$-BuLi $(2.86 \mathrm{M}$ in hexane, $4.80 \mathrm{ml}, 13.3 \mathrm{mmol})$ at $-78{ }^{\circ} \mathrm{C}$. The reaction mixture was stirred for $1 \mathrm{~h}$ before triisopropyl borate $(2.51 \mathrm{~g}, 3.10 \mathrm{~mL}$, $13.3 \mathrm{mmol}$ ) was added in one portion. The mixture was warmed to room temperature, stirred over night and then quenched with aqueous $\mathrm{HCl}(2.0 \mathrm{M}, 40 \mathrm{~mL})$ before adding a large amount of water for extraction with ethyl ether. The organic extracts were washed with brine and dried over $\mathrm{MgSO}_{4}$. Upon evaporating off the solvent, the crude product of 7-bromo-9,9-dioctyl-fluoren-2-yl-boronic acid was obtained. The crude product was refluxed with Pinacol $(1.80 \mathrm{~g}, 14.6 \mathrm{mmol})$ in anhydrous THF $(100 \mathrm{~mL})$ overnight. The mixture was cooled to room temperature, extracted with ethyl ether, 
washed with water and dried over $\mathrm{MgSO}_{4}$. Upon evaporating off the solvent, the residue was purified with column chromatography on silica gel with petroleum ether: ethyl acetate (8:1) as the eluent to afford $1 \mathrm{a}(5.94 \mathrm{~g}, 75 \%)$ as a light-yellow oil. ${ }^{1} \mathrm{H}$ NMR (300 MHz, $\left.\mathrm{CDCl}_{3}\right): \delta(\mathrm{ppm}) 7.81(\mathrm{~d}, J=7.14 \mathrm{~Hz}, 1 \mathrm{H}), 7.72(\mathrm{~s}, 1 \mathrm{H}), 7.66$ (d, $J=7.68 \mathrm{~Hz}, 1 \mathrm{H}), 7.58(\mathrm{dd}, J=6.97 \mathrm{~Hz}, J=1.92 \mathrm{~Hz}, 1 \mathrm{H}), 7.44-7.46(\mathrm{~m}, 2 \mathrm{H}), 1.94-1.97$ $(\mathrm{m}, 4 \mathrm{H}), 1.39(\mathrm{~s}, 12 \mathrm{H}), 1.03-1.27(\mathrm{~m}, 20 \mathrm{H}), 0.80-0.88(\mathrm{~m}, 6 \mathrm{H}), 0.48-0.63(\mathrm{~m}, 4 \mathrm{H}) .{ }^{13} \mathrm{C}$ NMR (75 MHz, $\left.\mathrm{CDCl}_{3}\right): \quad \delta(\mathrm{ppm}) 154.0,150.0,143.4,140.4,134.3,130.3,129.3$ $126.6,121.9,119.4,84.2,77.5,55.9,40.5,32.2,30.3,29.6,25.3,24.0,23.0,14.4$. Anal. Calcd. for $\mathrm{C}_{35} \mathrm{H}_{52} \mathrm{BBrO}_{2}$ : C, 70.59; H, 8.80. Found: C, 70.85; H, 8.48. Molecular Mass: Calcd for $\mathrm{C}_{35} \mathrm{H}_{52} \mathrm{BBrO}_{2}$ : 596. Found: 596. (GC-MS: 98.89\%).

\section{7'-Iodo-9',9'-dioctyl-fluoren-2'-yl-4,4,5,5,-tetramethyl-[1,3,2]dioxaborolane (1b)}

The procedure for the synthesis of 7'-bromo-9',9'-dioctyl-fluoren-2'-yl-4,4,5,5,tetramethyl-[1,3,2]dioxaborolane (1a) was followed to prepare $\mathbf{1 b}$ as a light-yellow oil in a 54\% yield. ${ }^{1} \mathrm{H}$ NMR $\left(300 \mathrm{MHz}, \mathrm{CDCl}_{3}\right): \quad \delta(\mathrm{ppm}) 7.80(\mathrm{~d}, J=7.62 \mathrm{~Hz}, 1 \mathrm{H})$, 7.72 (s, 1H), 7.64-7.67 (m, 3H), 7.46 (d, J=8.46 Hz, 1H), 1.91-1.97 (m, 4H), 1.39 (s, 12H), 1.03-1.22 (m, 20H), 0.80-0.85 (m, 6H), 0.46-0.66 (m, 4H). Anal. Calcd. For $\mathrm{C}_{35} \mathrm{H}_{52} \mathrm{BIO}_{2}$ : C, 65.43; H, 8.16. Found: $\mathrm{C}, 65.65 ; \mathrm{H}, 7.96$. Molecular Mass: Calcd for $\mathrm{C}_{35} \mathrm{H}_{52} \mathrm{BIO}_{2}$ : 642. Found: 642. (GC-MS: 96.91\%).

\section{2,7-Bis (2,2'-bithien-5-yl)-9,9-dioctylfluorene}

A solution of 2,7-dibromo-9,9-bis(n-octyl)-fluorene $(2.70 \mathrm{~g}, \quad 5.00 \mathrm{mmol})$, 
5-tributylstannyl-2,2'-bithiophene (4.60 g, $10.0 \mathrm{mmol})$, and $\mathrm{Pd}\left(\mathrm{PPh}_{3}\right)_{4}(230 \mathrm{mg}, 0.200$ mmol) in $100 \mathrm{~mL}$ of anhydrous DMF and Toluene (1:1) was stirred for $24 \mathrm{~h}$ at $85{ }^{\circ} \mathrm{C}$. The mixture was cooled to room temperature then poured into a large amount of water for extraction with methylene chloride. The organic extracts were washed with $\mathrm{KF}$ aqueous solution and brine before dried over $\mathrm{MgSO}_{4}$. Upon evaporating off the solvent, the residue was purified with column chromatography on silica gel with petroleum/methylene chloride (10:1) as the eluent to afford 2,7-bis (2,2'-bithien-5-yl)-9,9-dioctylfluorene (2.60 g, 72\%) as a yellow solid. ${ }^{1} \mathrm{H}$ NMR (300 $\left.\mathrm{MHz}, \mathrm{CDCl}_{3}\right): \delta \quad(\mathrm{ppm}) 7.70(\mathrm{~d}, J=3.96 \mathrm{~Hz}, 2 \mathrm{H}), 7.55-7.62(\mathrm{~m}, 4 \mathrm{H}), 7.30(\mathrm{~d}, J=1.88$ $\mathrm{Hz}, 2 \mathrm{H}), 7.23-7.25(\mathrm{~m}, 4 \mathrm{H}), 7.19$ (d, J=1.89 Hz, 2H), 7.04-7.07 (m, 2H), 2.00-2.05 (m, 4H), 1.08-1.17 (m, 20H), 0.77-0.81 (m, 6H), $0.70(\mathrm{~m}, 4 \mathrm{H})$. Anal. Calcd. For $\mathrm{C}_{45} \mathrm{H}_{50} \mathrm{~S}_{4}$ : C, 75.16; H, 7.01. Found: C, 75.30; H, 7.04.

\section{2,7-Bis (5-tributylstannyl -2,2'-bithien-5'-yl)-9,9-dioctylfluorene (8)}

Into a solution of 2,7-bis (2,2'-bithien-5-yl)-9,9-dioctylfluorene (1.00 g, $1.40 \mathrm{mmol})$ in anhydrous THF $(28 \mathrm{~mL})$ was added $n$-BuLi $(2.50 \mathrm{M}$ in hexane, $1.20 \mathrm{~mL}, 3.00$ mmol) at $-78{ }^{\circ} \mathrm{C}$. The reaction mixture was stirred for $1 \mathrm{~h}$ before tributyltin chloride $(1.10 \mathrm{~g}, 0.90 \mathrm{~mL}, 3.30 \mathrm{mmol})$ was added in one portion. The mixture was warmed to room temperature, stirred over night and then poured into a large amount of water for extraction with methylene chloride. The organic extracts were washed with $\mathrm{Na}_{2} \mathrm{CO}_{3}$ aqueous solution and brine before dried over $\mathrm{MgSO}_{4}$. Upon evaporating off the solvent, the crude product of $\mathbf{8}$ was obtained for next step without further purification. 
${ }^{1} \mathrm{H}$ NMR $\left(300 \mathrm{MHz}, \mathrm{CDCl}_{3}\right): \quad \delta(\mathrm{ppm}) 7.68$ (d, J=3.96 Hz, 2H), 7.60 (dd, J=3.96 Hz, $J=0.72 \mathrm{~Hz}, 2 \mathrm{H}), 7.55(\mathrm{~d}, J=0.71 \mathrm{~Hz}, 2 \mathrm{H}), 7.35$ (d, J=1.67 Hz, 2H), 7.30 (d, J=1.91 Hz, 2H), $7.18(\mathrm{~d}, J=1.86 \mathrm{~Hz}, 2 \mathrm{H}), 7.10(\mathrm{~d}, J=1.67 \mathrm{~Hz}, 2 \mathrm{H}), 2.00-2.02(\mathrm{~m}, 4 \mathrm{H}), 1.57-1.61$ (m, 6H), 1.33-1.41 (m, 6H), 1.07-1.17 (m, 26H), 0.80-0.95(m, 15H), $0.70(\mathrm{~m}, 4 \mathrm{H})$.

\section{7'-(Thien-2-yl)-9',9'-dioctyl-fluoren-2'-yl-4,4,5,5,-tetramethyl-[1,3,2]dioxaborola ne (2)}

\section{A. From 1a by Stille reaction}

In absence of light, a solution of 2-tributylstannyl thiophene (1.45 g, $3.90 \mathrm{mmol}), \mathbf{1 a}$ (2.32 g, $3.90 \mathrm{mmol})$, and $\mathrm{Pd}\left(\mathrm{PPh}_{3}\right)_{4}(135 \mathrm{mg}, 0.120 \mathrm{mmol})$ in $80 \mathrm{~mL}$ of anhydrous DMF and Toluene $(1: 1)$ was stirred for $24 \mathrm{~h}$ at $85^{\circ} \mathrm{C}$. The mixture was cooled to room temperature then poured into a large amount of water for extraction with methylene chloride. The organic extracts were washed with brine before dried over $\mathrm{Na}_{2} \mathrm{SO}_{4}$. Upon evaporating off the solvent, the residue was purified with column chromatography on silica gel with petroleum ether:ethyl acetate $(16: 1)$ as the eluent to afford $2(1.80 \mathrm{~g}, 77 \%)$ as a light yellow oil. $\quad{ }^{1} \mathrm{H}$ NMR $\left(300 \mathrm{MHz}, \mathrm{CDCl}_{3}\right): \quad \delta(\mathrm{ppm})$ $7.84(\mathrm{~d}, J=7.56 \mathrm{~Hz}, 1 \mathrm{H}), 7.11-7.78(\mathrm{~m}, 3 \mathrm{H}), 7.59-7.65(\mathrm{~m}, 2 \mathrm{H}), 7.42$ (dd, J=7.20 Hz, $J=1.05 \mathrm{~Hz}, 1 \mathrm{H}), 7.33(\mathrm{dd}, J=10.2 \mathrm{~Hz}, J=1.02 \mathrm{~Hz}, 1 \mathrm{H}), 7.15(\mathrm{~m}, 1 \mathrm{H}), 2.02-2.05(\mathrm{~m}$, $4 \mathrm{H}), 1.43(\mathrm{~s}, 12 \mathrm{H}), 1.06-1.20(\mathrm{~m}, 20 \mathrm{H}), 0.81-0.98(\mathrm{~m}, 6 \mathrm{H}), 0.55-0.71(\mathrm{~m}, 4 \mathrm{H})$. Molecular Mass: Calcd for $\mathrm{C}_{39} \mathrm{H}_{55} \mathrm{BO}_{2} \mathrm{~S}$ : 598.4016. Found: 598.4020 (MALDI-TOF MS). (HPLC: 95.67\%)

\section{B. From $1 b$ by Stille reaction}


The procedure for the synthesis of $\mathbf{2}$ from $1 \mathrm{a}$ was followed to prepare $\mathbf{2}(0.22 \mathrm{~g}$, 58.4\%) from 1b and 2-tributylstannyl thiophene. (HPLC: 92.27\%)

\section{From la by Kumada reaction}

A solution of thienyl magnesium bromide $(1.1 \mathrm{~mL}, 0.8 \mathrm{M} / \mathrm{L}, 0.88 \mathrm{mmol}), 1 \mathrm{a}(0.50 \mathrm{~g}$, $0.84 \mathrm{mmol})$, and $\mathrm{Pd}(\mathrm{dppf}) \mathrm{Cl}_{2}(7.0 \mathrm{mg}, 0.0086 \mathrm{mmol})$ in $10 \mathrm{~mL}$ of anhydrous THF was stirred for $48 \mathrm{~h}$ at room temperature. The mixture was poured into a large amount of water for extraction with methylene chloride. The organic extracts were washed with brine and dried over $\mathrm{Na}_{2} \mathrm{SO}_{4}$. Upon evaporating off the solvent, the residue was purified with column chromatography on silica gel with petroleum ether:ethyl acetate (16:1) as the eluent to afford $2(0.42 \mathrm{~g}, 86 \%)$ as a light yellow oil. (HPLC: $96.30 \%)$

\section{From 1 b by Kumada reaction}

The procedure for the synthesis of $\mathbf{2}$ from 1a by Kumada reaction was followed to prepare $2(0.12 \mathrm{~g}, 22 \%)$ as a yellow oil from $\mathbf{1 b}$ and thienyl magnesium bromide. (HPLC: $52.35 \%)$

\section{7'-(2,2'-bithien-5-yl)-9',9'-dioctyl-fluoren-2'-yl-4,4,5,5,-tetramethyl-[1,3,2]dioxab} orolane (3)

\section{A. From la by Stille reaction}

The procedure for the synthesis of $\mathbf{2}$ from $\mathbf{1 a}$ by Stille reaction was followed to prepare 3 from 1a and 5-tributylstannyl-2,2'-bithiophene in a yield of 79\%. ${ }^{1} \mathrm{H}$ NMR (300 MHz, $\left.\mathrm{CDCl}_{3}\right): \delta(\mathrm{ppm}) 7.85(\mathrm{~d}, J=7.59 \mathrm{~Hz}, 1 \mathrm{H}), 7.71-7.78(\mathrm{~m}, 3 \mathrm{H})$, 7.58-7.64 (m, 2H), $7.33(\mathrm{~d}, J=3.72 \mathrm{~Hz}, 1 \mathrm{H}), 7.26-7.27(\mathrm{~m}, 2 \mathrm{H}), 7.21(\mathrm{~d}, J=3.81 \mathrm{~Hz}$, 
1H), 7.06-7.09 (m, 1H), 2.01-2.08 (m, 4H), $1.43(\mathrm{~s}, 12 \mathrm{H}), 1.07-1.23(\mathrm{~m}, 20 \mathrm{H})$, 0.80-0.90 (m, 6H), 0.61-0.71 (m, 4H). ${ }^{13} \mathrm{C}$ NMR (75 MHz, $\left.\mathrm{CDCl}_{3}\right): \quad \delta(\mathrm{ppm})$ 152.6, $150.5,144.3,143.9,141.1,137.9,136.9,134.2,133.7,129.3,128.3,127.9,125.0$ $124.9,124.7,124.0,120.9,120.3,119.4,84.1,77.8,77.6,77.4,74.0,55.6,40.6,32.2$, 30.3, 29.6, 28.3, 27.3, 25.3, 24.1, 23.0, 17.9, 14.4, 14. Anal. Calcd. for $\mathrm{C}_{43} \mathrm{H}_{57} \mathrm{BO}_{2} \mathrm{~S}_{2}$ : C, 75.85; H, 8.44. Found: C, 75.63; H, 8.11. Molecular Mass: Calcd for $\mathrm{C}_{43} \mathrm{H}_{57} \mathrm{BO}_{2} \mathrm{~S}_{2}$ : 680.3893. Found: 680.3808 (MALDI-TOF MS).

\section{B. From $2 b$ by Stille reaction}

The procedure for the synthesis of $\mathbf{3}$ from $\mathbf{1 a}$ by Stille reaction was followed to prepare $\mathbf{3}$ from $\mathbf{1 b}$ and 5-tributylstannyl-2,2'-bithiophene in a yield of $60 \%$.

\section{7'-(4,4'-Diphenyl)-9',9'-dioctyl-fluoren-2'-yl-4,4,5,5,-tetramethyl-[1,3,2] dioxabor} olane (4)

The procedure for the synthesis of $\mathbf{3}$ by Stille reaction was followed to prepare $\mathbf{4}$ from 1a and 4-tributylstannyl-biphenyl in a yield of $45 \% .{ }^{1} \mathrm{H}$ NMR $\left(300 \mathrm{MHz}, \mathrm{CDCl}_{3}\right): \delta$ (ppm) 7.60-7.84 (m, 15H), 7.31-7.50 (m, 4H), 2.02-2.05 (m, 4H), $1.43(\mathrm{~s}, 12 \mathrm{H})$, 1.07-1.23 (m, 20H), 0.80-0.90 (m, 6H), 0.61-0.71 (m, 4H). ${ }^{13} \mathrm{C}$ NMR $(75 \mathrm{MHz}$ $\left.\mathrm{CDCl}_{3}\right): \quad \delta(\mathrm{ppm}) 152.1,150.2,143.8,140.8,140.6,140.0,133.9,128.9,127.6,127.4$ $127.1,121.5,120.5,120.5,119.1,83.8,77.5,77.0,76.6,55.4,31.8,30.1,29.2,25.0$, 23.8, 22.6, 16.2, 14.1. Molecular Mass: Calcd for $\mathrm{C}_{47} \mathrm{H}_{61} \mathrm{BO}_{2}$ : 668.4765. Found: 668.4766 (MALDI-TOF MS). 
7'-(4-Phenyl-styrenyl)-9',9'-dioctyl-fluoren-2'-yl-4,4,5,5,-tetramethyl-[1,3,2]dioxa borolane (5)

\section{A. From 1a}

In absence of light, a solution of 4-phenylstyrene $(0.21 \mathrm{~g}, 1.16 \mathrm{mmol}), 1 \mathrm{a}(0.69 \mathrm{~g}$, $1.16 \mathrm{mmol})$, tris $(o$-tolyl $)$ phosphine $(77 \mathrm{mg}, 0.25 \mathrm{mmol})$, and $\mathrm{Pd}(\mathrm{OAc})_{2}(13 \mathrm{mg}, 0.057$ mmol) in $10 \mathrm{~mL}$ of anhydrous DMF and $10 \mathrm{~mL}$ of $\mathrm{Et}_{3} \mathrm{~N}$ was stirred for $24 \mathrm{~h}$ at $110{ }^{\circ} \mathrm{C}$. The mixture was cooled to room temperature and then poured into a large amount of water for extraction with methylene chloride. The organic extracts were washed with brine and dried over $\mathrm{Na}_{2} \mathrm{SO}_{4}$. Upon evaporating off the solvent, the residue was purified with column chromatography on silica gel with petroleum ether:ethyl acetate (16:1) as the eluent to afford $5(0.44 \mathrm{~g}, 55 \%)$ as a light yellow solid. ${ }^{1} \mathrm{H}$ NMR (300 $\left.\mathrm{MHz}, \mathrm{CDCl}_{3}\right): \delta(\mathrm{ppm}) 7.82(\mathrm{~d}, J=7.92 \mathrm{~Hz}, 1 \mathrm{H}), 7.64-7.76(\mathrm{~m}, 9 \mathrm{H}), 7.34-7.55(\mathrm{~m}$, 4H), $7.24(\mathrm{~d}, \mathrm{~J}=4.44 \mathrm{~Hz}, 2 \mathrm{H}), 1.99-2.05(\mathrm{~m}, 4 \mathrm{H}), 1.40(\mathrm{~s}, 12 \mathrm{H}), 1.05-1.25(\mathrm{~m}, 20 \mathrm{H})$, 0.79-0.83 (m, 6H), $0.63(\mathrm{~m}, 4 \mathrm{H}) .{ }^{13} \mathrm{C} \mathrm{NMR}\left(75 \mathrm{MHz}, \mathrm{CDCl}_{3}\right): \quad \delta(\mathrm{ppm}) 152.3,150.6$, $144.2,141.3,141.1,140.6,137.2,137.0,134.2,129.8,129.2,128.0,127.8,127.3$, $126.0,121.3,119.4,84.1,77.9,77.4,77.0,66.3,55.5,40.7,32.2,30.4,29.6,25.4$, 24.1, 23.0, 15.7, 14.5. Anal. Calcd. for $\mathrm{C}_{49} \mathrm{H}_{63} \mathrm{BO}_{2}$ : C, 84.70; H, 9.14. Found: C, 84.92; $\mathrm{H}$, 9.15. Molecular Mass: Calcd for $\mathrm{C}_{49} \mathrm{H}_{63} \mathrm{BO}_{2}$ : 694.4921. Found: 694.5467 (MALDI-TOF MS).

\section{B. From $1 b$}

The procedure for the synthesis of $\mathbf{5}$ from $\mathbf{1 a}$ by Heck reaction was followed to prepare $\mathbf{5}$ from $\mathbf{1 b}$ in a yield of $50 \%$. 


\section{References}

[1] (a) Geng, Y.; Culligan, S.; Trajkovska, A.; Wallace, J.; Chen, S. Chem. Mater. 2003, 15, 542. (b) Jo, J.; Chi, C.; Höger, S.; Wegner, G.; Yoon, D. Chem. Eur. J. 2004, 10, 2681. (c) Geng, Y.; Trajkovska, A.; Katsis, D.; Ou, J.; Culligan, S.; Chen, S. J. Am. Chem. Soc. 2002, 124, 8337. (d) Ding, J.; Day, M.; Robertson, G; Roovers, J. Macromolecules 2002, 35, 3474. (e) Grisorio, R.; Mastrorilli, P.; Nobile, C.; Romanazzi, G..; Suranna, G.; Meijer, E. Tetrahedron Letters 2004, 45, 5367. (f) Lee, S.; Toshikazu, N.; Tetsuo, T. Org. Lett. 2001, 3, 2005.

[2] Bäuerle, P.; Würthner, F.; Götz, G.; Effenberger, F. Synthesis 1993, 1099.

[3] (a) Keigo, F.; Masanori, K. Topic in Current Chemistry 2002, 129, 88. (b) Barbarella, G..; Favaretto, L.; Sotgiu, G..; Zambianchi, M.; Fattori, V.; Cocchi, M.; Cacialli, F.; Gigli, G.; Cingolani, R. Adv. Mater 199911 1378. (c) Geng, Y.; Chen, A.; Ou, J.; Chen, S. Chem. Mater. 2003, 15, 4352. (d) Nehls, B.; Asawapirom, U.; Füldner, S.; Preis, E.; Farrell, T. Adv. Funct. Mater. 2004, 14, 352. (e) May, P.; Larsen, S. Syn. Lett. 1997, 8, 895.

[4] (a) Li, B.; Li, Jing.; Fu, Y.; Bo, Z. J. Am. Chem. Soc. 2004, 126, 3430. (b) Thiemann, D.; Pearson, D.; Thoennes, D. Can. J. Chem. 1973, 51, 3808

[5] Thomas, K.; Manfred, E.; Petra, F.; Ursula, H.; Wilfried, K. Chem. Ber. 1994, 127, 127.

[6] Tsolakis, P. K.; Kallitsis, J. K. Chem. Eur. J. 2003, 9, 936. 


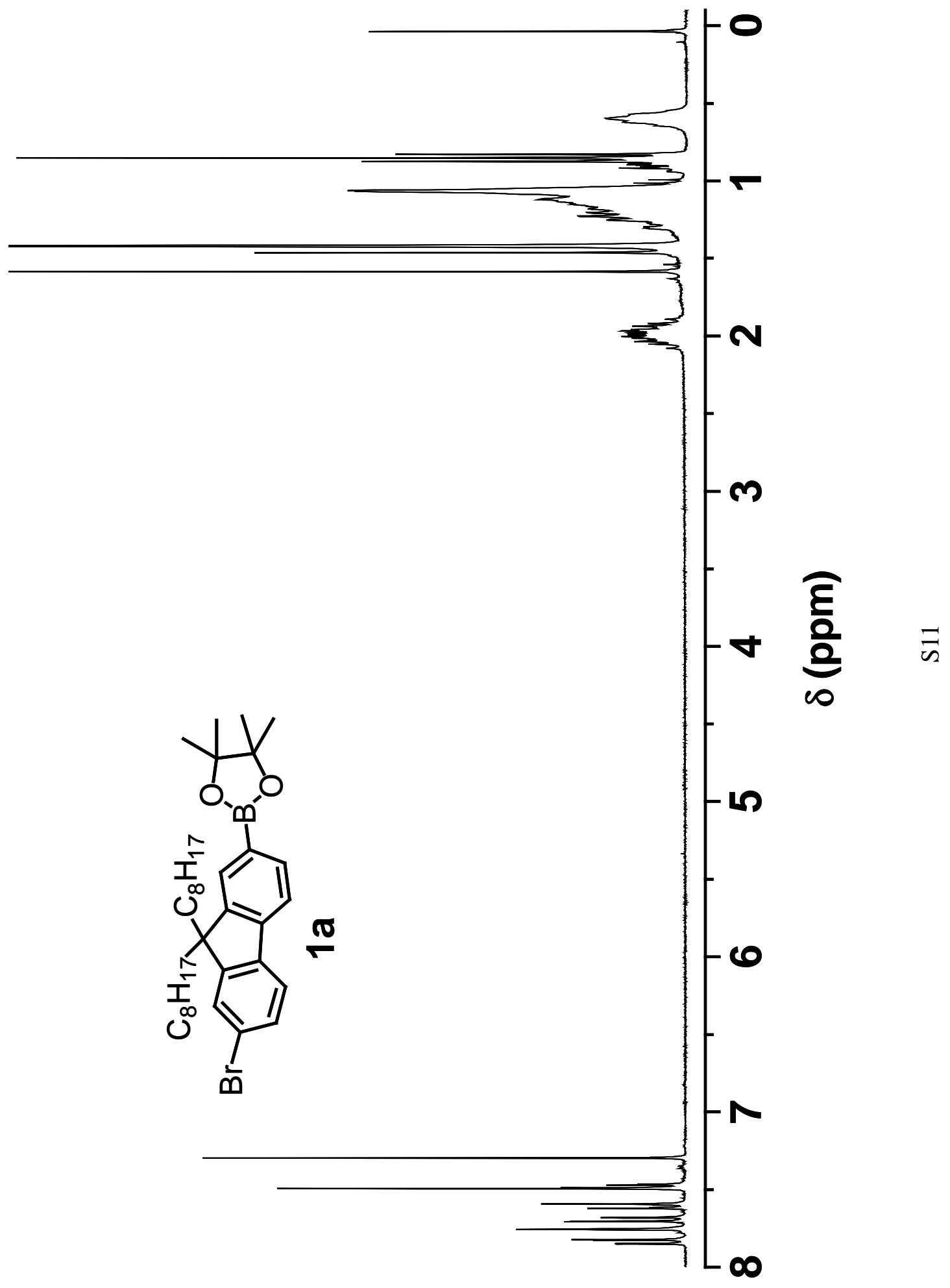




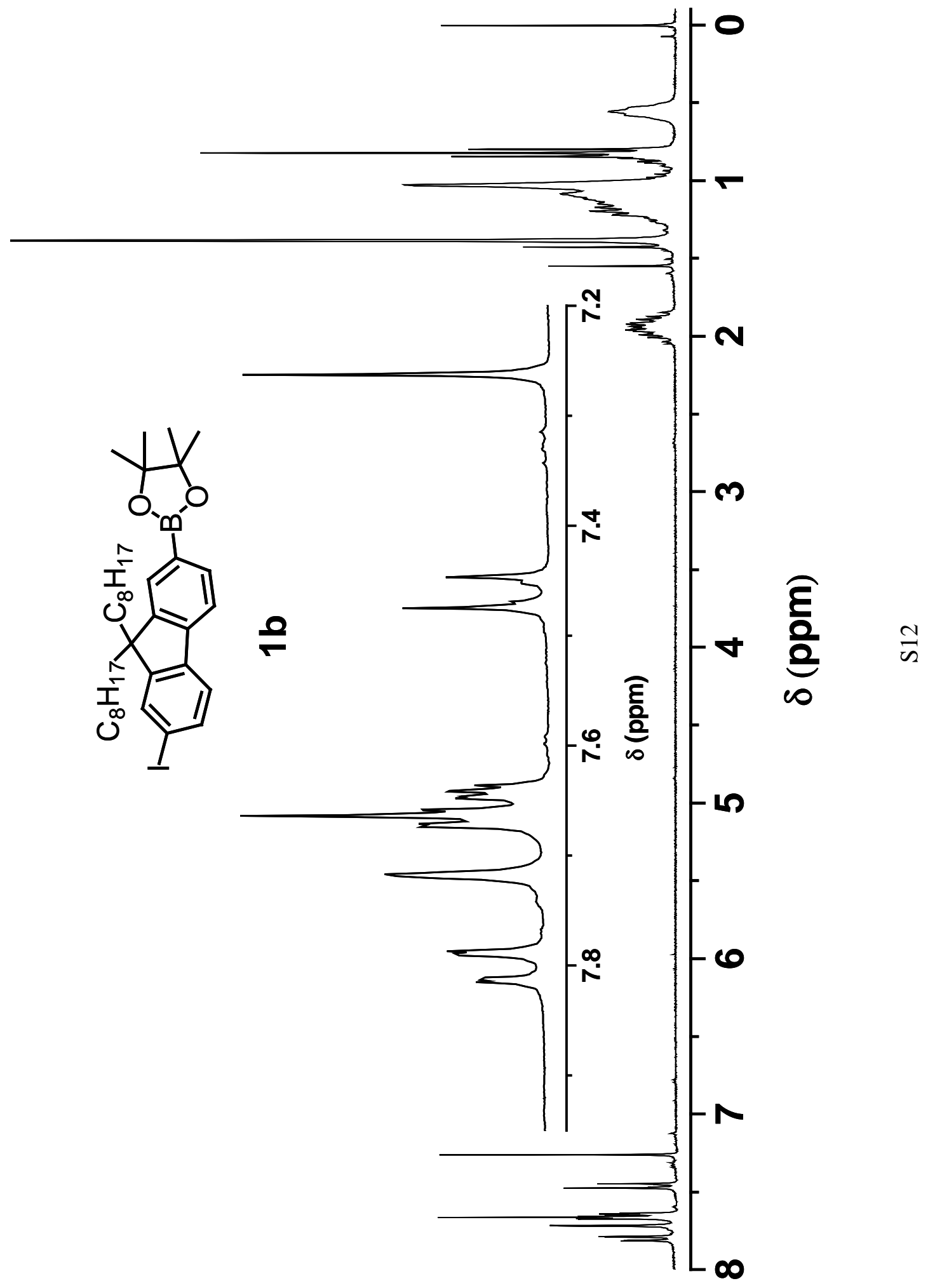




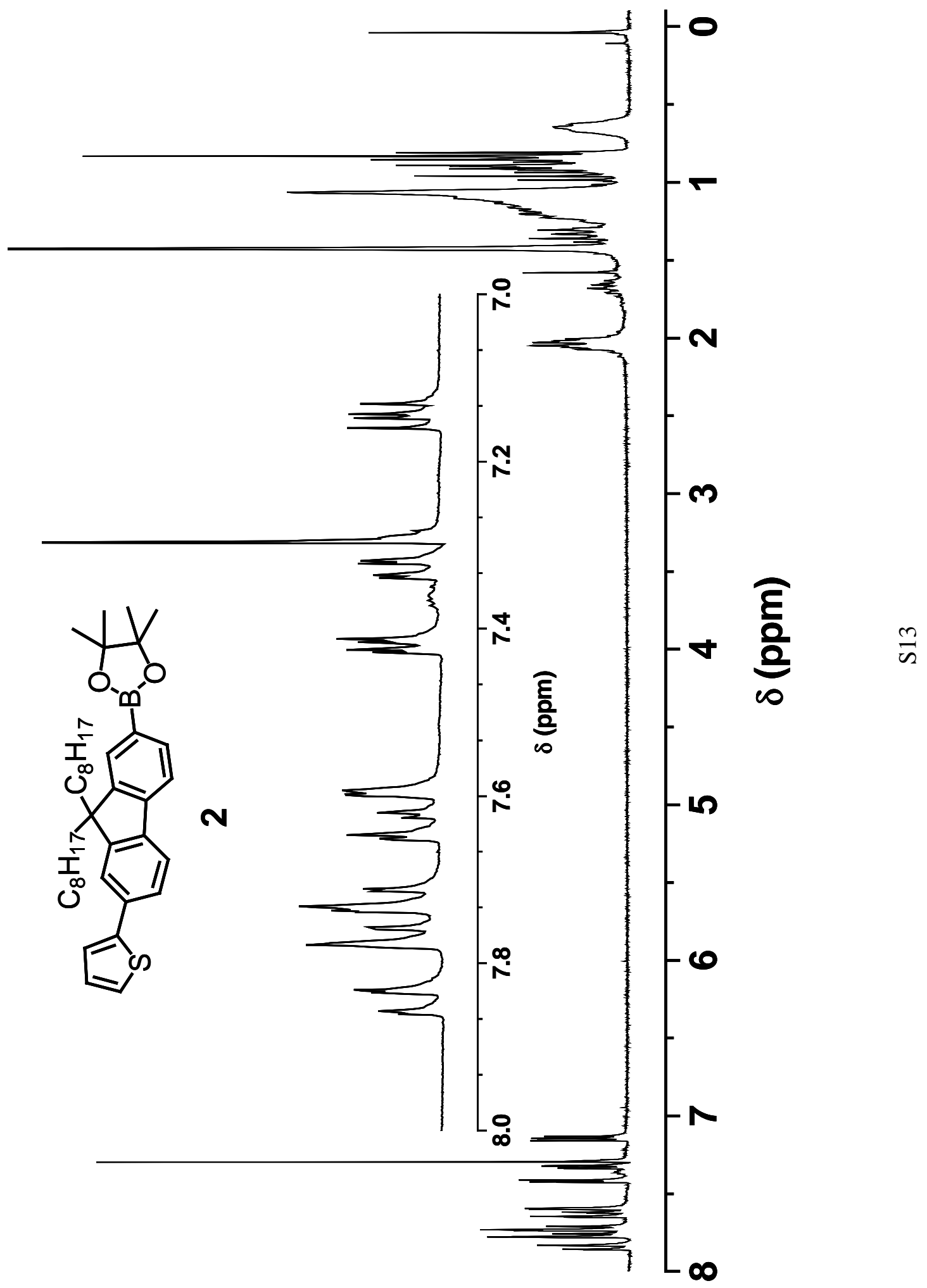




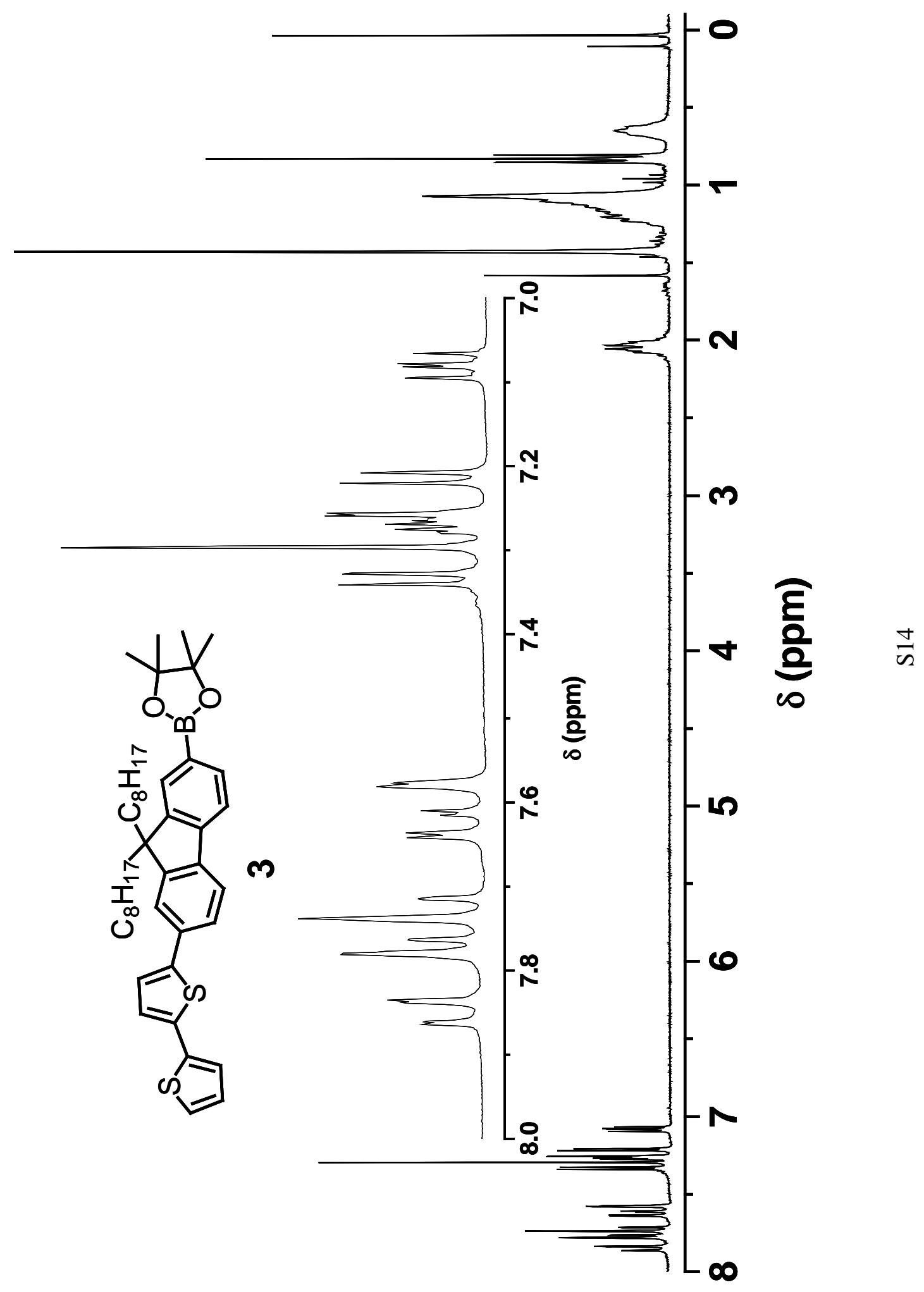




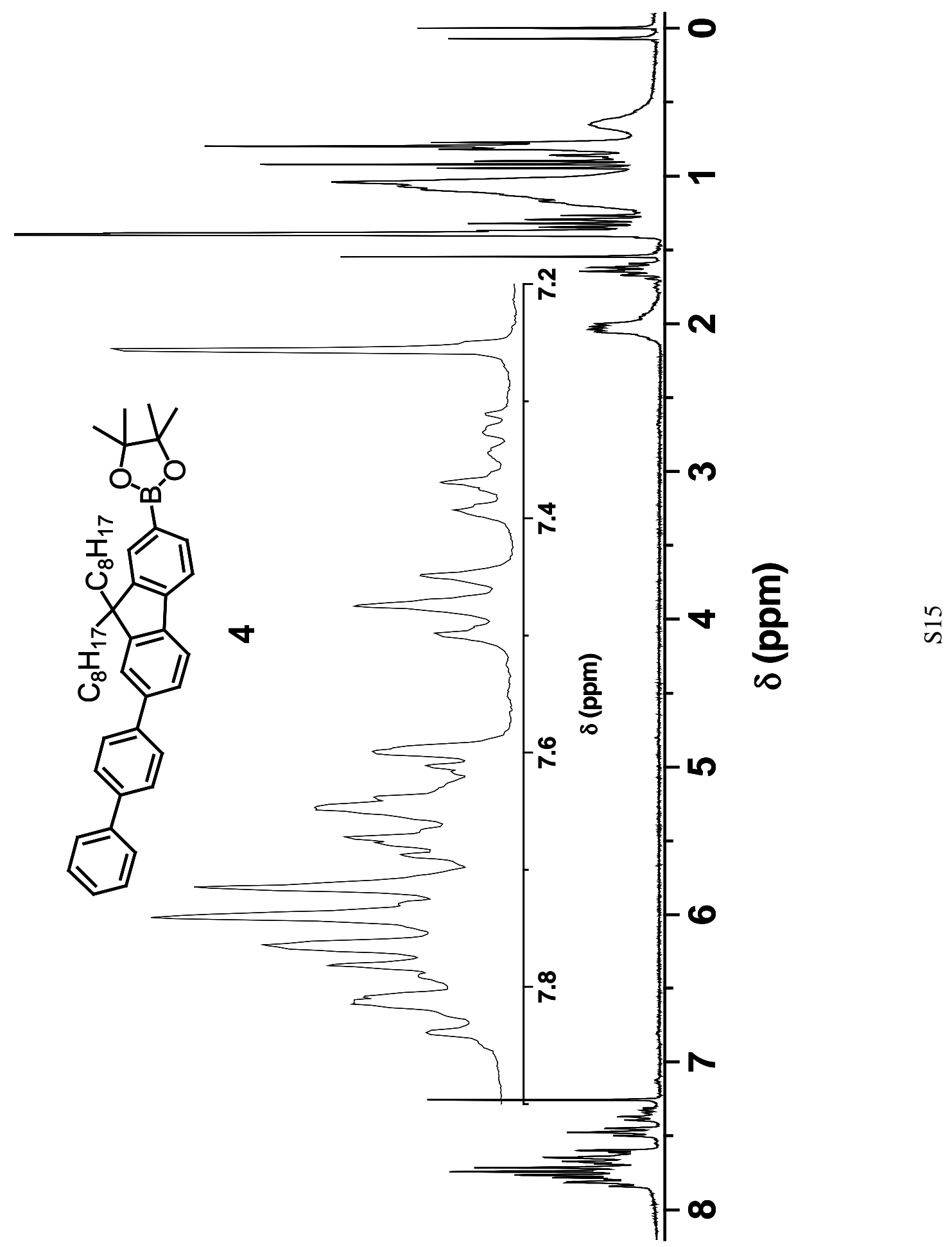




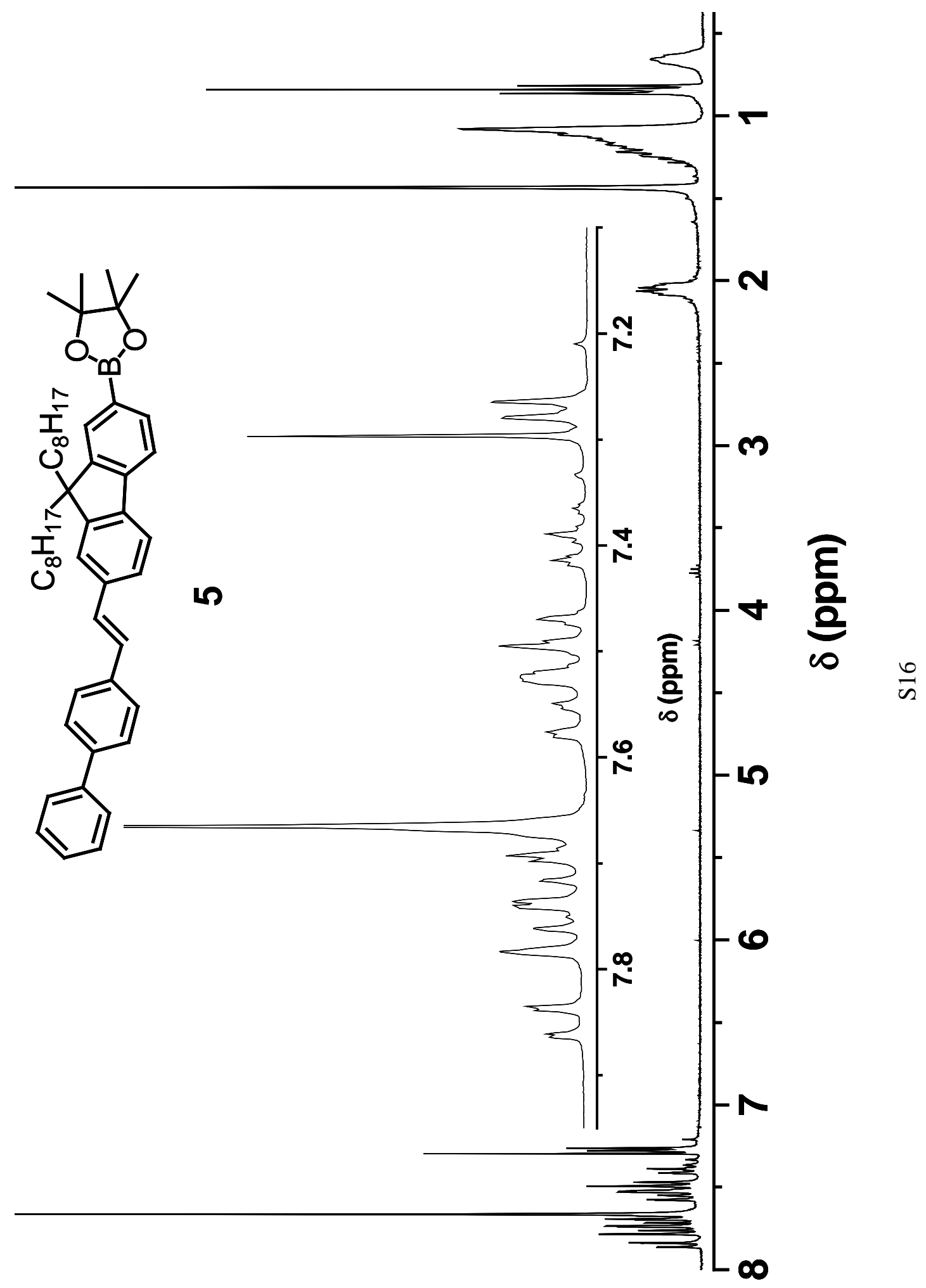




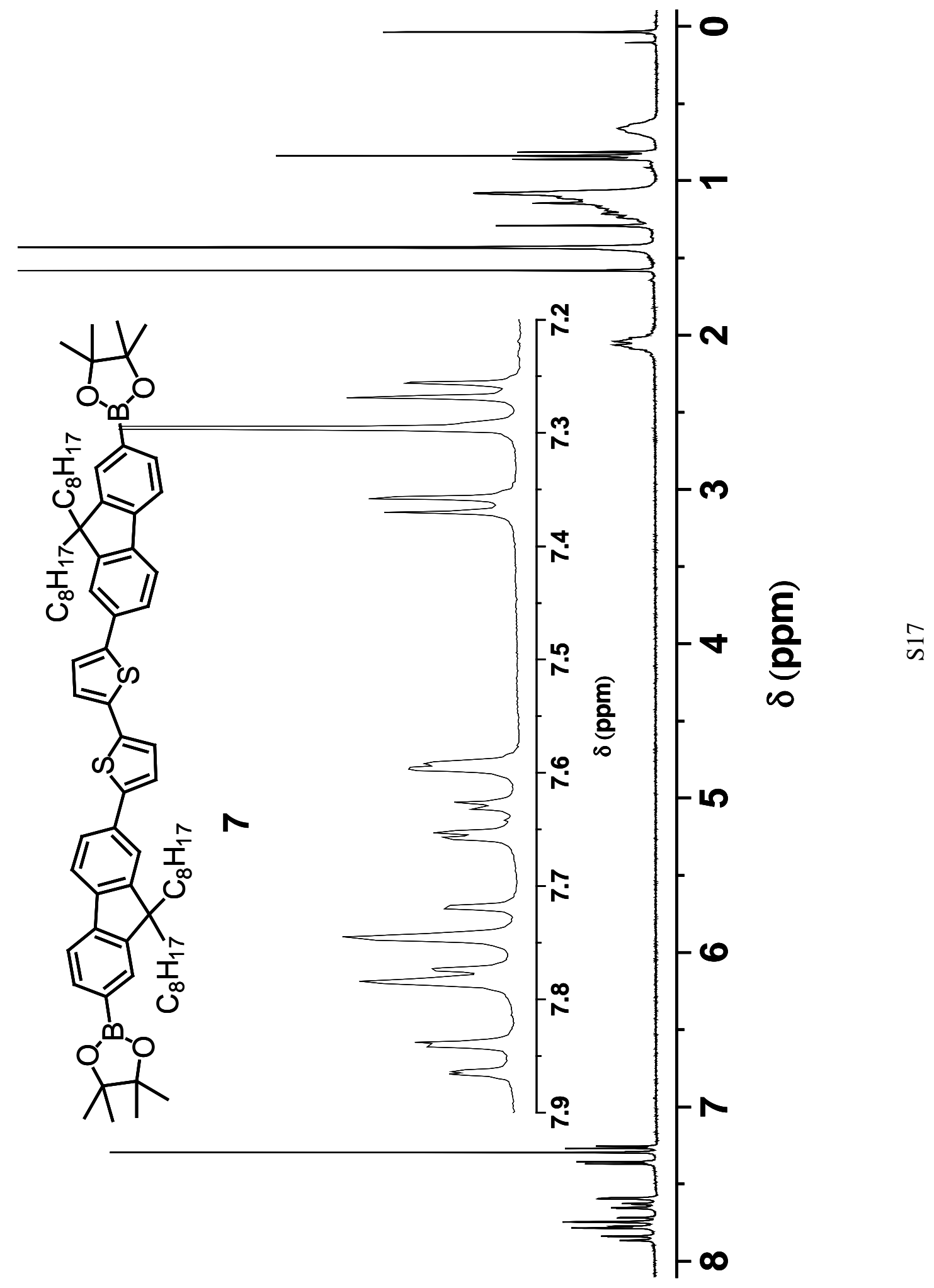




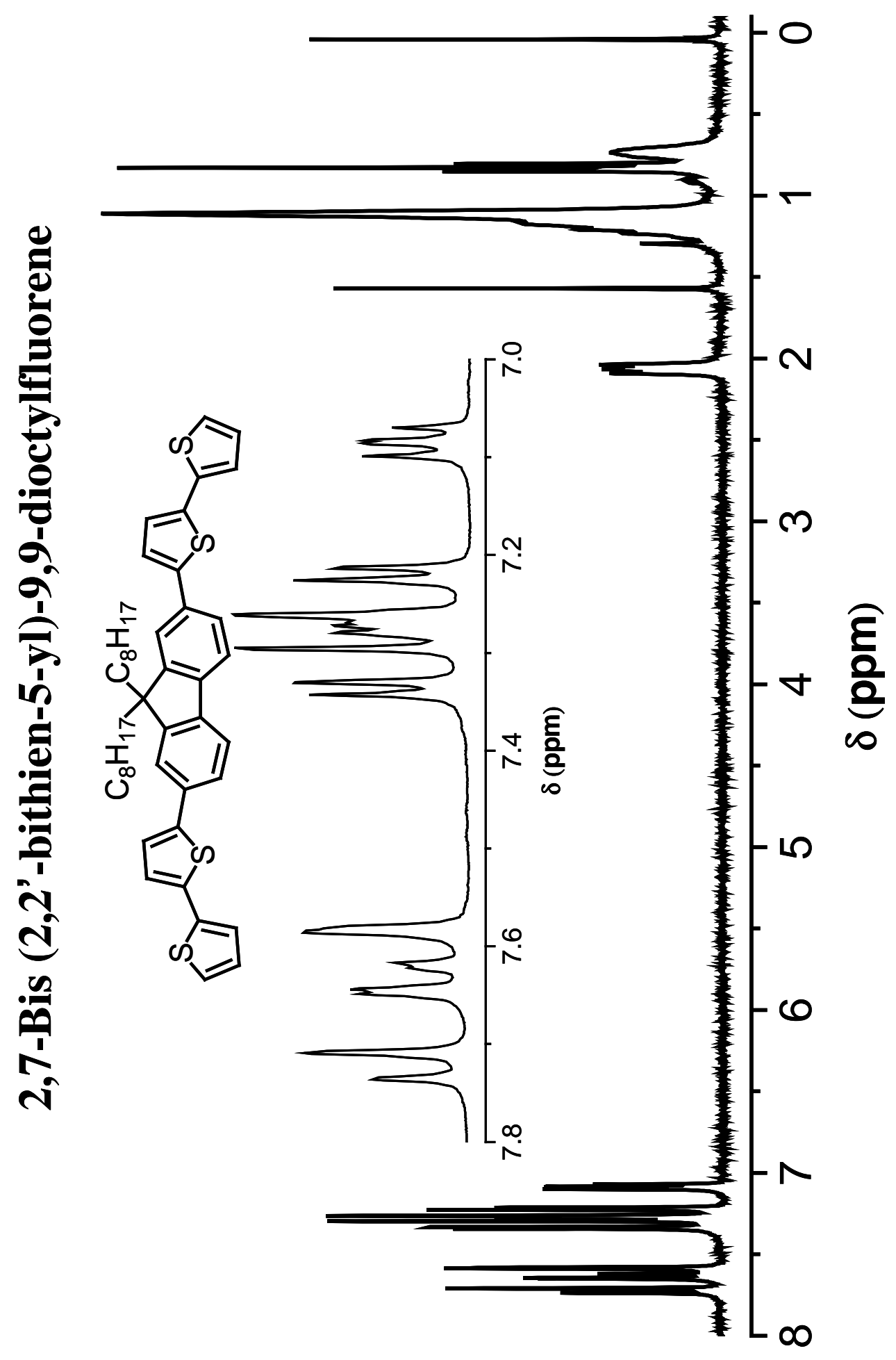

$\frac{\infty}{\sim}$ 


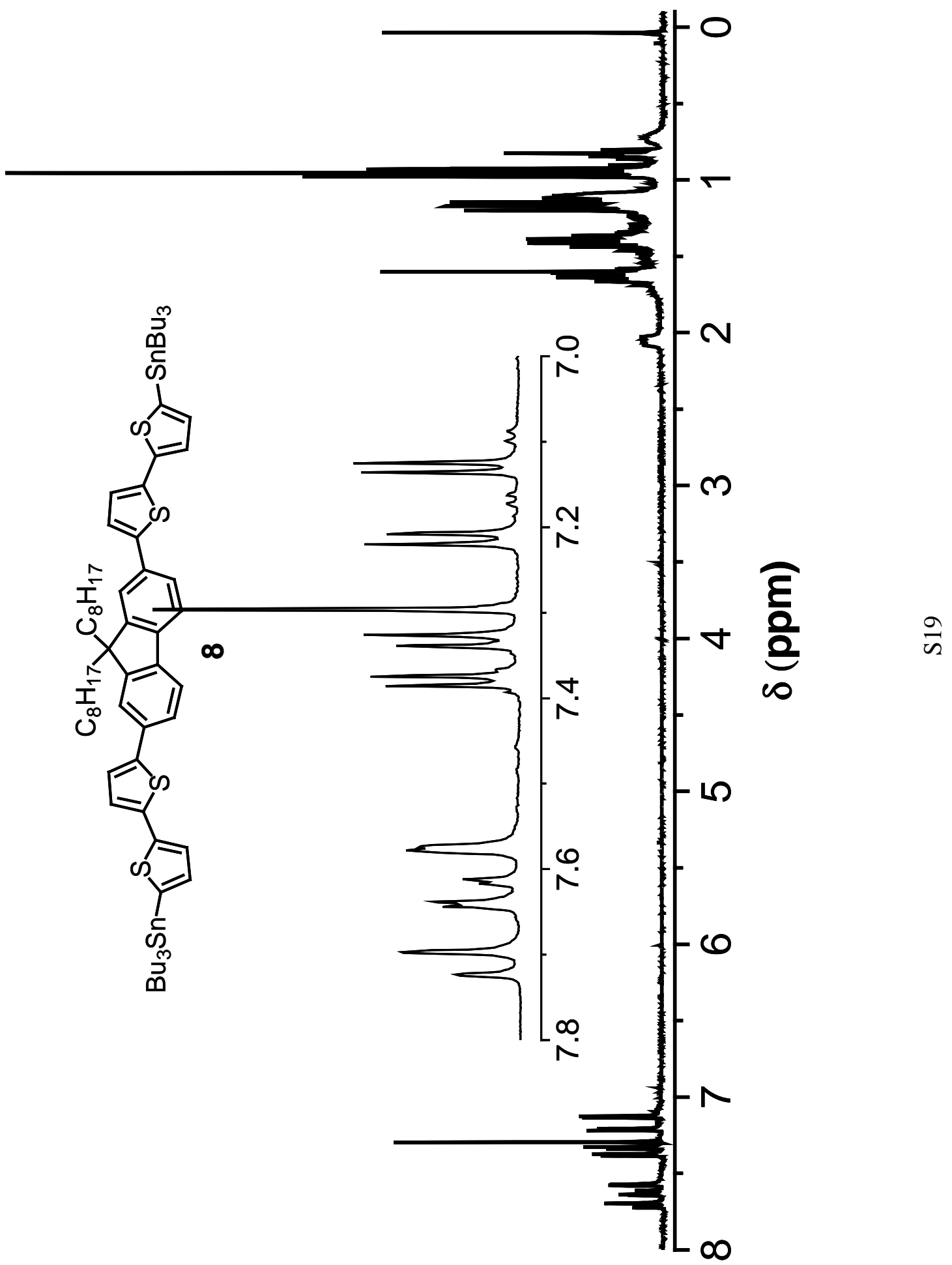




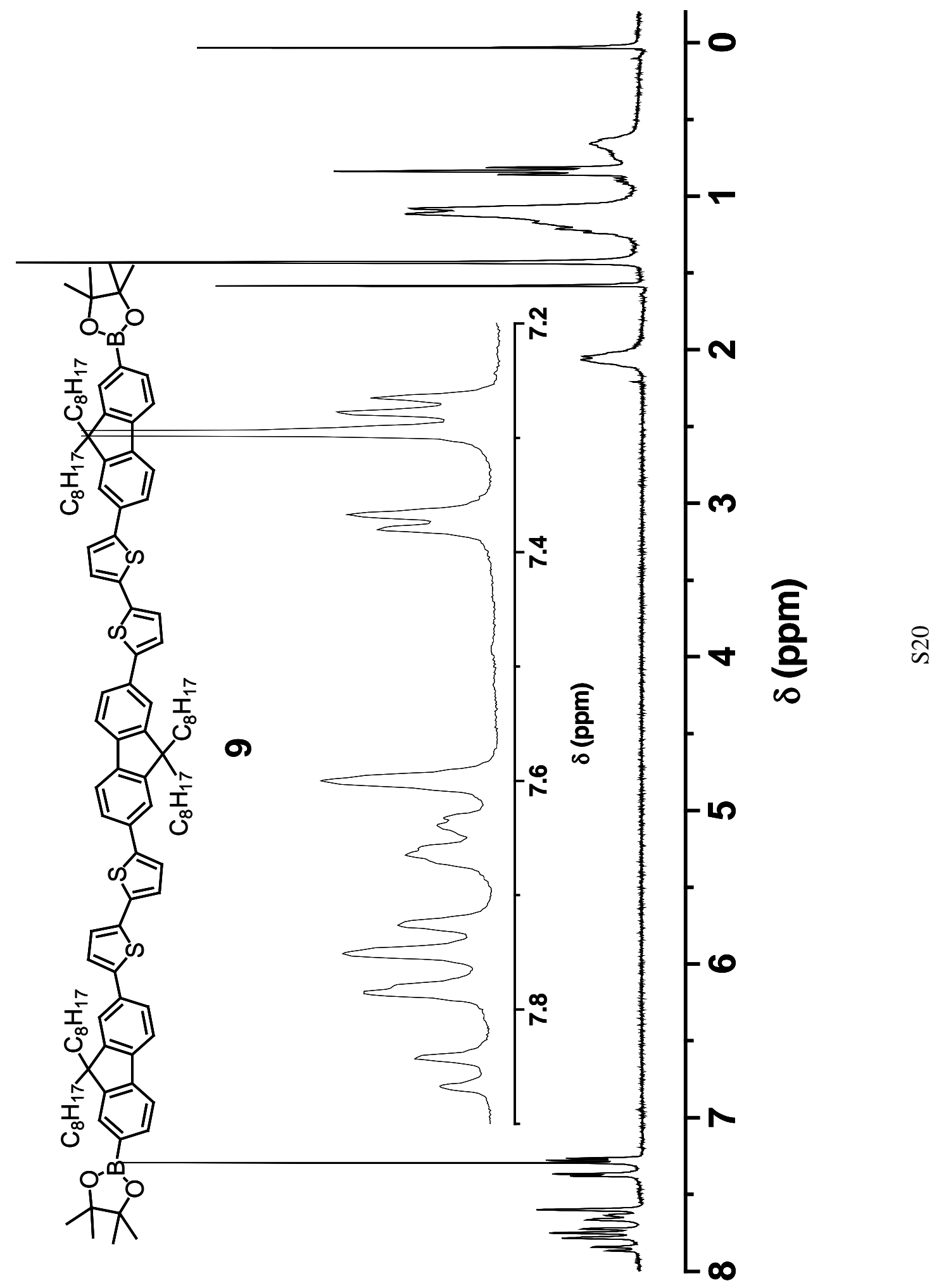




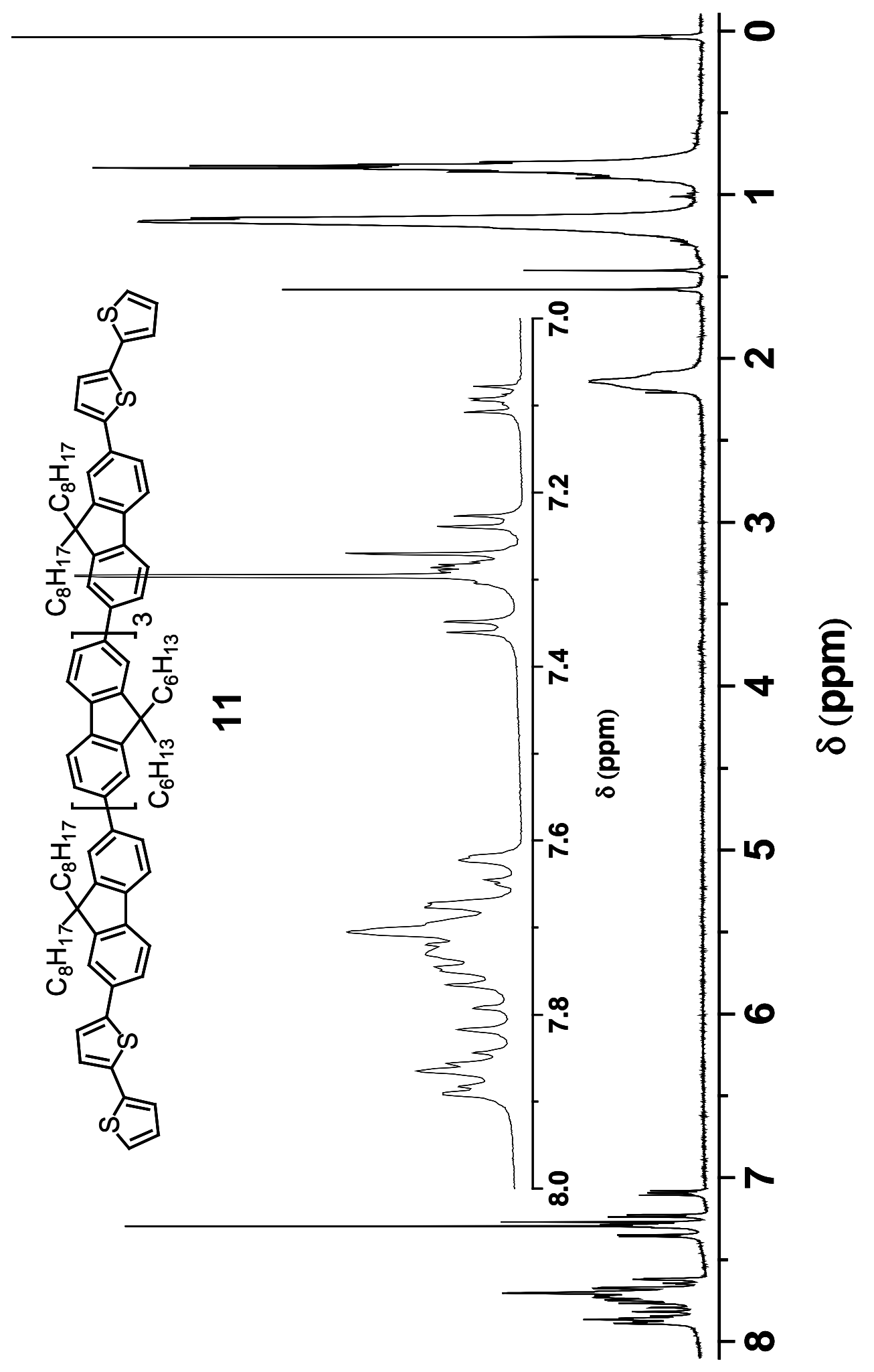




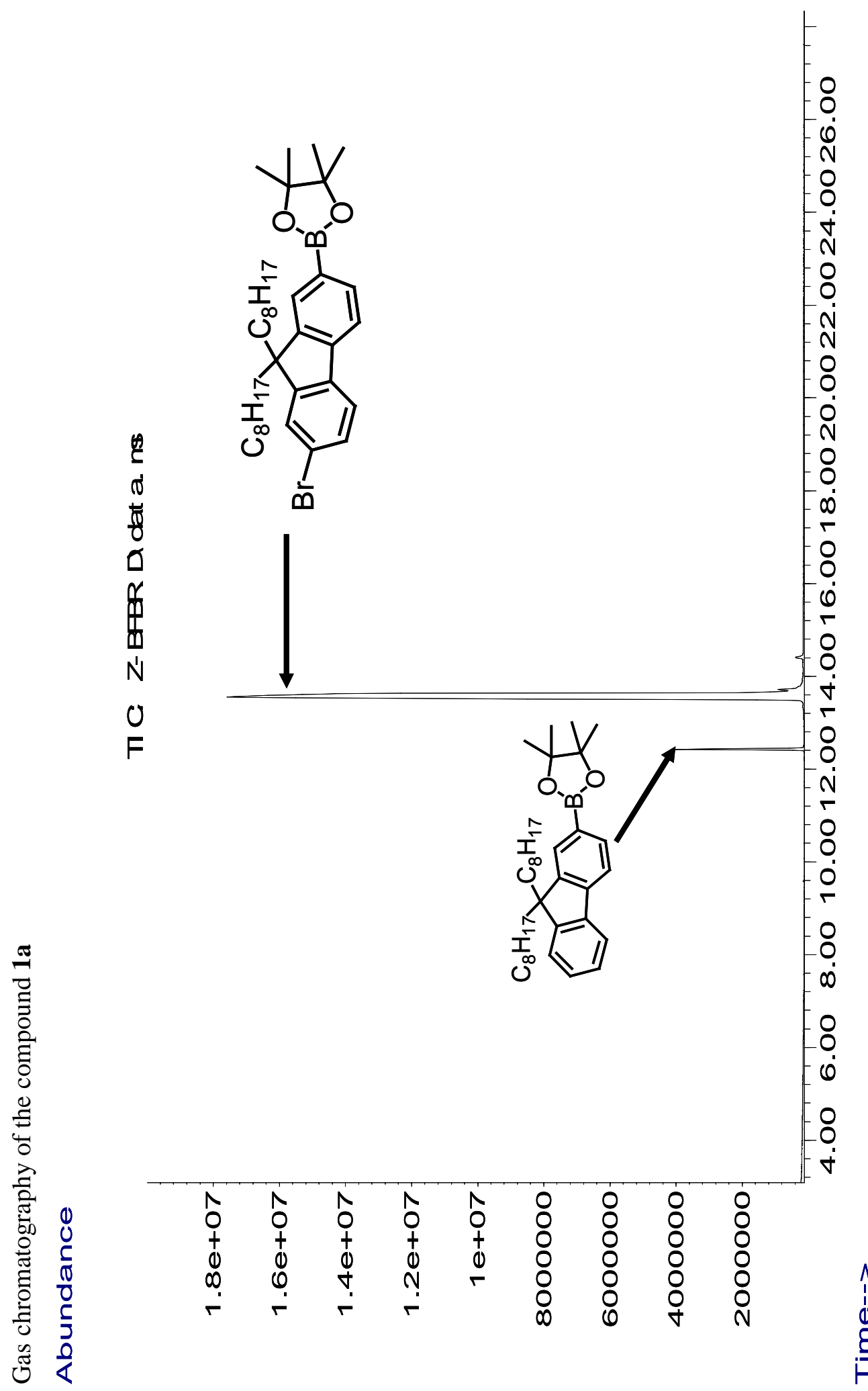

ฆี 


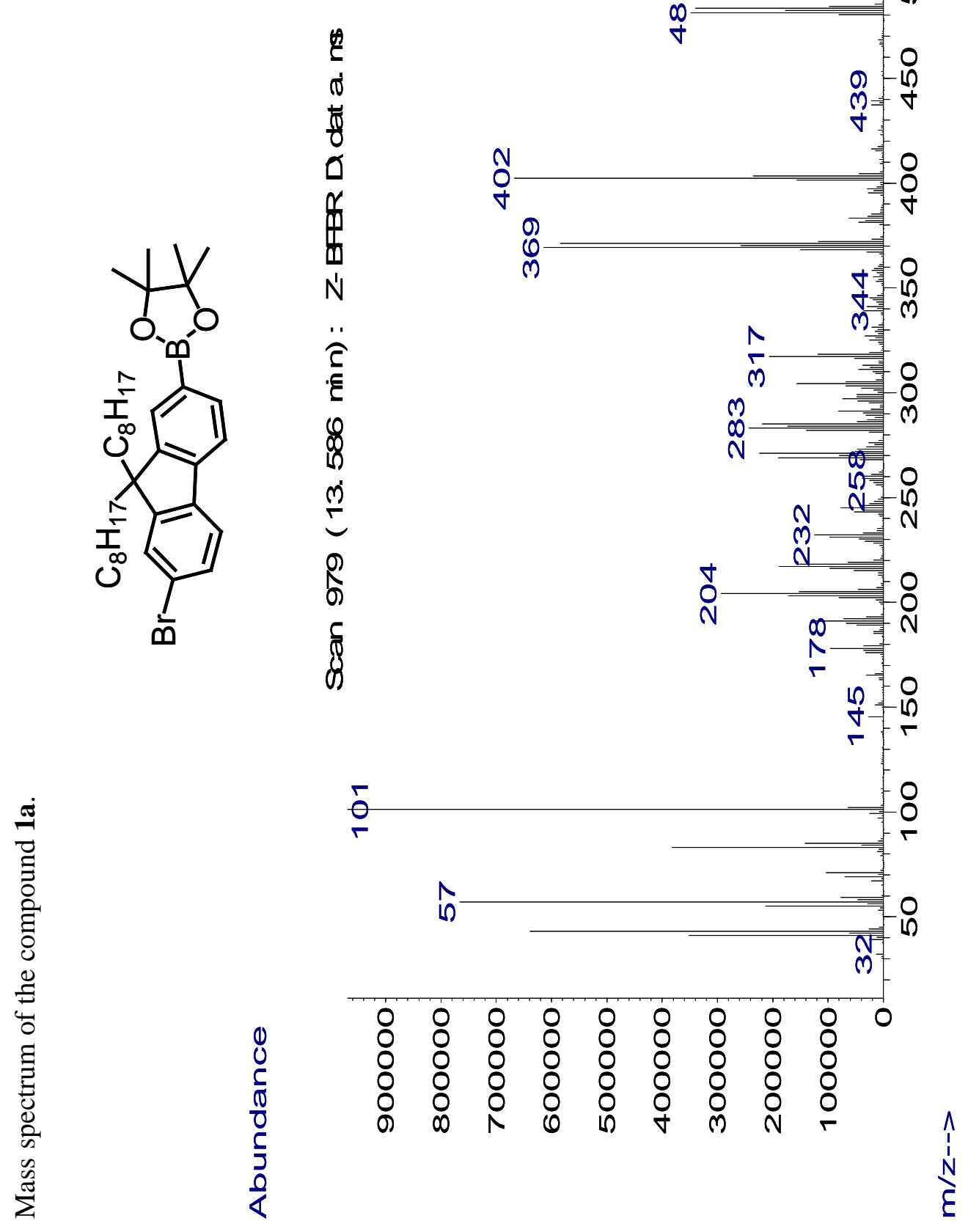




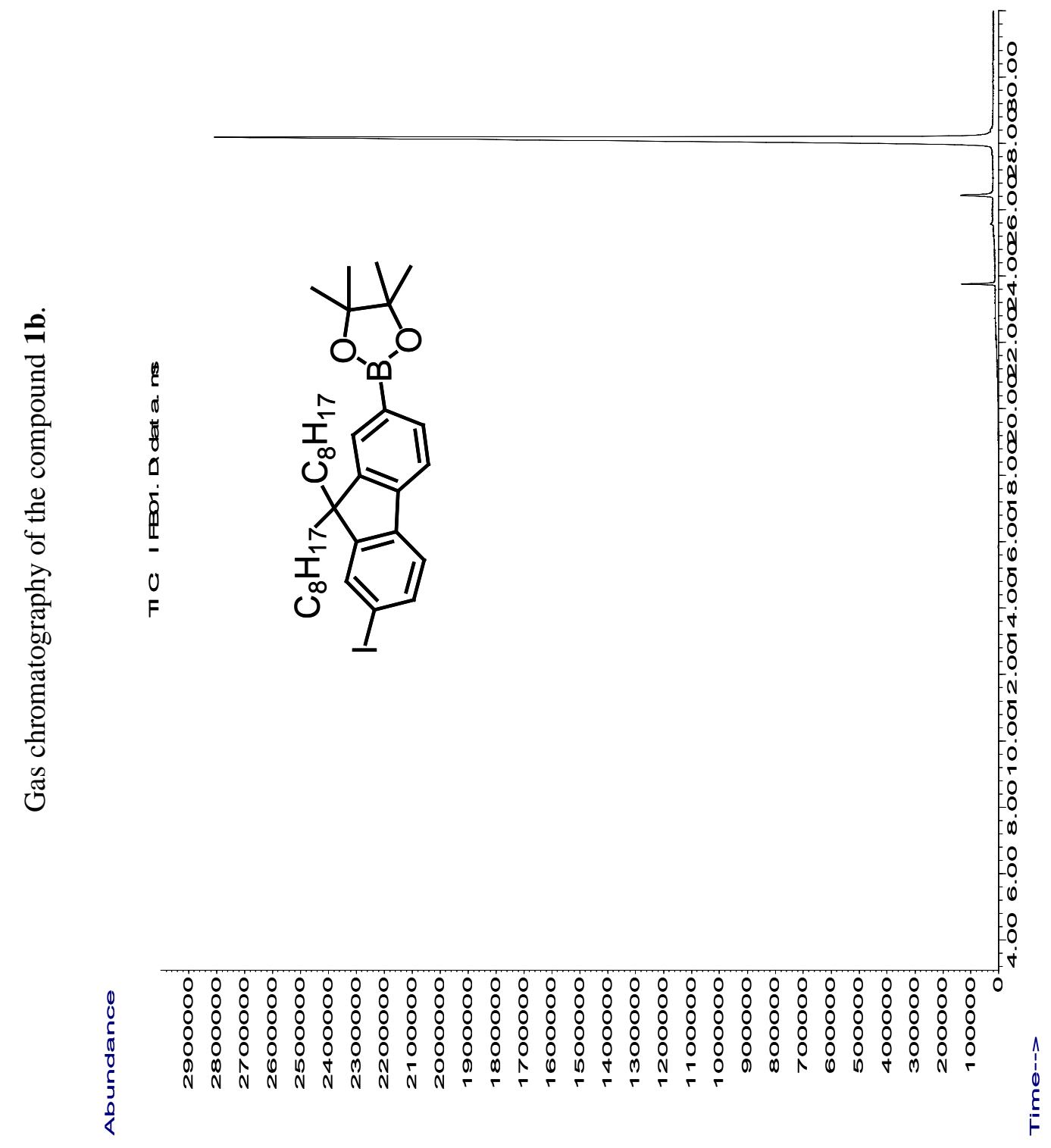

范 


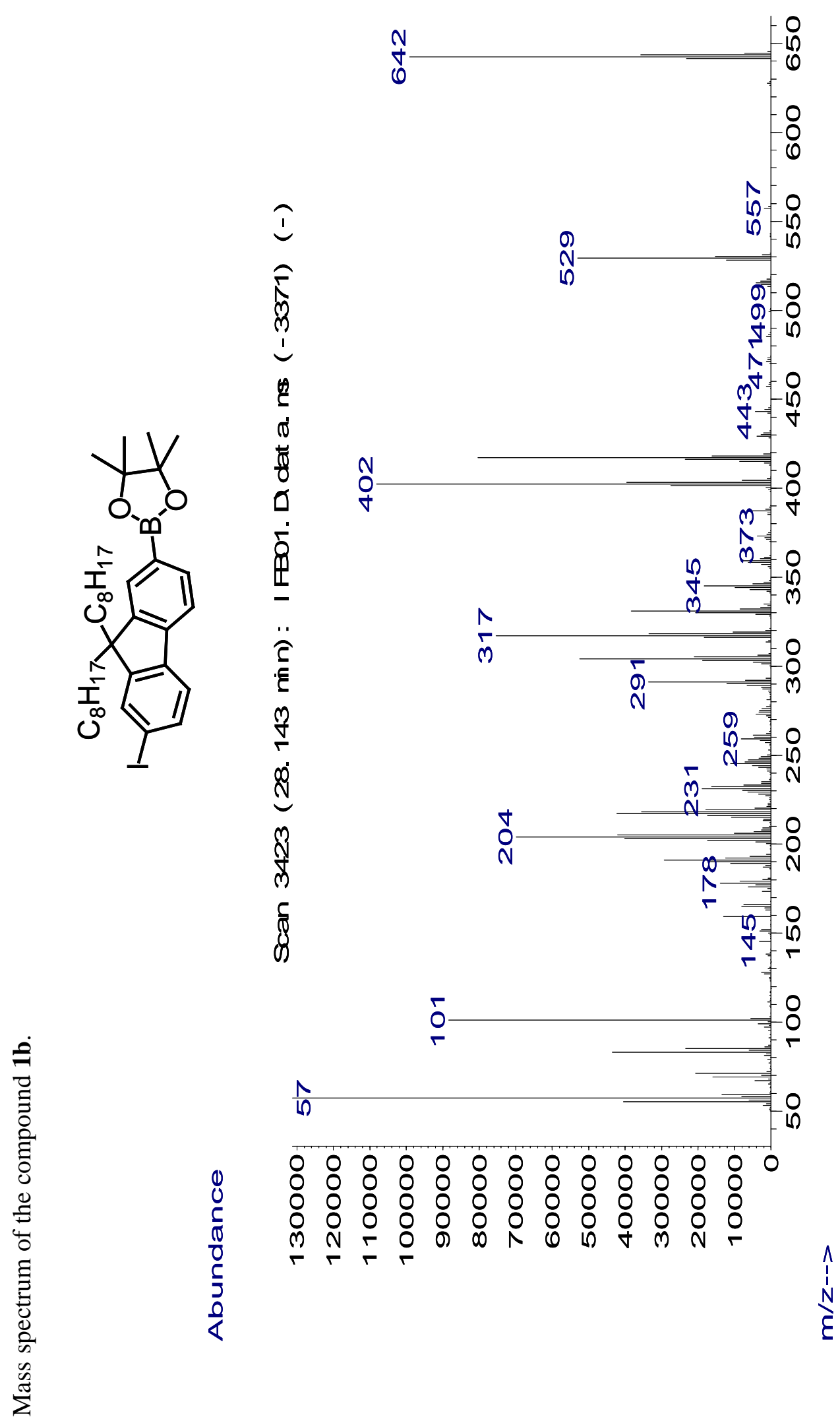




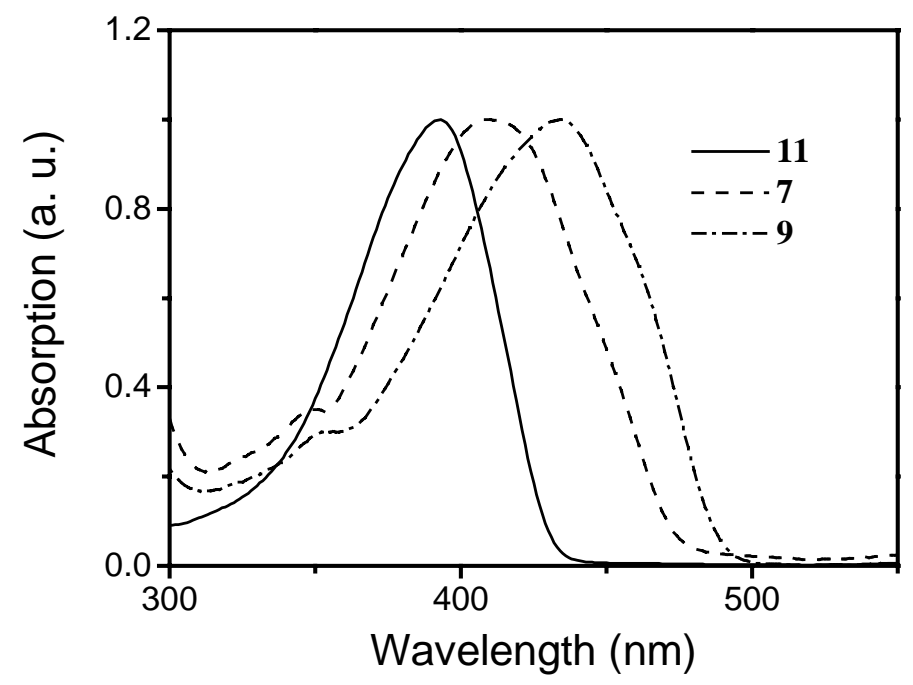

UV-vis absorption spectra of compound 7, 9, and 11 in $\mathrm{CHCl}_{3}$ solution with the concentration of $3.5 \pm 0.5 \times 10^{-6} \mathrm{M}$. 